\title{
POLITICAL AND ECONOMIC ROOTS OF THE TURBULENT POLITICAL SYSTEM, OR WHY AND HOW THE WORLD OF 1991-2021 WAS BORN
}

https://doi.org/10.18485/iipe_balkans_rssc.2020.ch2

\begin{abstract}
The world political system of the last 30 years (since December 1989) is characterized by immense and growing turbulence: more and more acts of Western aggression (Yugoslavia, Afghanistan, Iraq, Libya), more and more local conflicts to the benefit of transnational corporations, more and more grey zones (the latter fact reflects both the 'fading away' of the nationstate and the criminalization of world politics and world economy). Is there one single factor explaining these events, or do we just have a mosaic of disorderly chaos? Being far from cheap conspirology discourse and working strictly within the political-economic approach to the history of the capitalist system, which is largely a cryptohistory, the author thinks that the fact determining the turbo transformation of world politics is the dismantling of the capitalist system (The fact that this system does not correspond to the current world is acknowledged officially even by the 'wizards of Davos'). Partly it is elemental, but to a larger extent, it is the process of chaos organized by global elites. The problem is that in the process of the battle for the future, first, there are more and more contradictions between rival elite groups (the Anglo-Saxons and Europeans, moderate and radical globalists, financiers and industrialists, etc., let alone occult differences), and, secondly, the process of dismantling spins out of control increasingly. This creates a combination of organized and disorderly chaos in world politics, which makes it difficult to analyze it adequately.
\end{abstract}

Keywords: world political system, capitalism, chaos, global elites, political economy.

\section{INTRODUCTION}

It became commonplace that we live in a more and more turbulent world, a world torn apart by the economic crisis, political instability, regional

\footnotetext{
${ }^{1}$ Director of the Institute of System-Strategic Studies, Director of the Centre of Russian Studies, Supervisor of the Fursov's School of Analysis, Moscow University for the Humanities; active member of the International Academy of Science (Innsbruck, Austria). E-mail: system-strategy@mail.ru.
} 
wars, the spread of grey zones, the acts of aggression on the part of the West (against Yugoslavia, Afghanistan, Iraq, Libya, Syria). 'The veil of darkness is rising over the world' - this phrase from J.R.R. Tolkien's 'The Lord of the Rings' seems to be increasingly appropriate to current state affairs in the world. It is evident the dividing line between a rather stable world of the Cold War epoch and the Age of Turbulence was being drawn through 1991, the year the USSR formally died (informally, i.e., it really died on 2-3 December 1989).

The Age of Turbulence began in 1991, and according to the prognostications, the economic crisis which is to come in 2020, 2021 or 2022, seems to draw the line behind the Age of Turbulence. That does not mean that turbulence will be over. On the contrary, it will acquire a new quality of the terminal crisis of the capitalist system. The fact that capitalism is an outdated phenomenon and does not correspond to the contemporary world is evident even to 'wizards of Davos' and some of the Western European political leaders.

Bearing in mind that all historical chronological divisions and subdivisions are to some extent arbitrary, I will state the following nevertheless. With the period of 1991-2021, we have a single chronohistorical bloc of its own - like, for example, the 'watershed period' of 1871-1914 (or 1929/33 and 'es trentes glorieuses' of 1945-1975).

The said period is characterized by the rise of the three interconnected phenomena: financialism, social and economic inequality, and chaotization (both orderly and disorderly) of world politics. Is there one single factor explaining these phenomena and events pertinent to them? I do believe there is. It is the demise of the capitalist system, which is both a 'natural' dissolution and an 'artificial' dismantling by a part of global elites. Just like the feudal seigneurs of the $15^{\text {th }}$ century who, in order to keep power, property, and privileges (status) dismantled the half- (but only half!) dying feudalism, the capitalists of the $20^{\text {th }}$ century began dismantling capitalism. The Age of Turbulence is one of the stages - an important one - in this process. But the theme of the present article is neither this age, nor the process of historical murder of the capitalist dragon by its masters - the 'Masters of history', as Disraeli used to call them, or the 'Masters of world game' according to the Russian writer O. Markeev.

Here I would like to ponder on the question of the origins of the Age of Turbulence. The answer to it can clarify not only the problem of the emerging and the beginning of this chronobloc, but, first, of its inner mechanics, and, secondly, of its end. 
Pondering on the question of historical (political-economic) routs of 'les trentes inglorieuses' one should try to answer several 'naïve' questions, and as always naïve questions are followed by the most important and essential ones:

1) what is capitalism; the specificity of its dynamics in the $20^{\text {th }}$ century;

2) the 1960s as the turning point in the development of the capitalist system and the Modernity; the role of the Soviet leadership in the transition to a negative evolutionary trend;

3) the 1980s as the birth cradle of the Age of Turbulence.

\section{CAPITALISM IN THE 20th CENTURY: 'GUNS BEFORE BUTTER'}

It seems that the essence of capitalism and, hence, its definition is an evident fact. But as Sherlock Holmes used to say, there is nothing more deceptive than an obvious fact. Capitalism is not a simple and linear triumph of capital and cannot be limited or deduced to capital only. Capital existed before capitalism and will exist after its demise. The fact that capitalism is a complicated social and institutional system, which ensures constant accumulation of capital (time) and its expansion (space), while at the same time limiting capital in its own long-term and holistic interests is more often overlooked than not (Fursov, 1996, p. 3). Having no such limitation, very soon, capital would eat to the end both society and nature (biosphere). The means of limitation were the state, civil society, politics, and mass education. I would like to stress: they used to limit not capital as such, but its long-term and holistic interests as opposed to partial and short-term or, at least, medium-term ones.

The whole history of capitalism was its struggle against its limitations; in fact, it was a driving force of capitalism as a system, one of its main contradictions. And the chief arbiters between the sides ('extremes') of this contradiction were, of course, closed supranational groups. So capitalism is not just capital; it is the unity of capital with its social institutional limitations under the control of supra-state, supranational closed groups whose main interest is not just capitalism but power; capitalism serves them as the means; but at the same time, they are the tool of self-correction and selfdevelopment of the capitalist system. The whole picture reminds of M.C. Escher's famous drawing 'Relativity'.

Now let us have a look at the dynamics of the capitalist system. The 'long $16^{\text {th }}$ century' (1453-1648) was the period of the genesis of capitalism. As 
Hegel used to say, when a thing is emerging, it does not exist yet. So the genetic phase is, in fact, a precapitalist one. Then we have the early phase, roughly from 1650 to the 1780s (1648-1789). The second, the mature phase lasted from 1780 to the 1910s (1789-1914) and the third phase, late capitalism from $1910-$ ? (1914-2050?).

During the first two phases or periods of its development, capitalism in its expansion covered the whole world. In the $19^{\text {th }}$ century, the last stride was the 'Scramble for Africa'. Further development presupposed conflicts not between the core and the periphery, but between core states and European semiperipheral empires for the repartition of the colonial periphery, which meant imperialist wars between European states. The driving force of development in these circumstances became the destruction of the industrial base of this or that core state or empire and further development in the form of the postwar reconstruction of what had been destroyed. This means that in the late $19^{\text {th }}$ - early $20^{\text {th }}$ century, the economic dynamics of capitalism was actually exhausted and became a secondary factor. It was the extra-economic dynamics that came to the foreground, became the first and most important factor.

The motor of development of the capitalist system after the World War I was the industrial reconstruction of the USSR and Germany; after the World War II, it was the reconstruction of the USSR, Germany and Japan (hence economic miracles: 'the Soviet', 'the German' and 'the Japanese' ones). But by the early 1960s, all miracles were over, the development potentiality of the postwar reconstruction was finished. More than that, further industrial economic and scientific-technological progress of the core countries of the capitalist system became an obvious menace for the dominant groups of core capitalism because it was strengthening the social and political positions of the middle class and the upper layer of the working class. The social and political turbulence of the 1960s became a sign of trouble, of misfortune for the ruling circles of the capitalist system.

Their reaction to this challenge of history took three main forms:

1) They tried to slow down industrial and scientific-technological progress in the name of ecology, of ecological menace. The leading role here was played by the Club of Rome (1968), which proposed the concept of 'zero growth'. It was not just an economic operation, but also a cultural, a psychohistoric one: for example, the Tavistock Institute was charged with the task 'to stamp out cultural optimism of the sixties'. Very soon, the place of science fiction was taken by fantasy literature. And if one compares scientific and technological inventions of the first half of the $20^{\text {th }}$ century to 
that of the second half, the picture will be the following: plenty of inventions in the first half and rather few - mobile phone, the internet and the personal computer - in the second. We have a real slowdown in scientifictechnological progress.

2) The second direction was the counteroffensive of the upper classes against the middle class and the working class under a neoliberal banner. Thatcherism and Reaganomics became the social weapons of the strong against the weak, an evident manifestation of the 'revolt of the elites' as opposed to 'the revolt of the masses' of the first half of the $20^{\text {th }}$ century.

3) All these activities could be successful only in case the Soviet Union would not use the situation for its benefit. Hence, the third direction was to neutralize the Soviet Union by (false) promising to integrate it into the capitalist world as an equal partner. The Soviet leadership was offered several 'attractions':

- the cooperation in the sphere of global ecology;

- the organization of the rise of oil prices by means of the Arab-Israeli conflict;

- the 'Moon bargain';

- the détente in world politics.

And the Soviet leadership answered in the affirmative.

This brings us to an extremely important question - the role of the Soviet leadership, the role of the Soviet elites in the destruction of the USSR, and the coming of the Age of Turbulence.

\section{THE USSR: A LEAP IN THE DARK (FROM ANTICAPITALISM TO CONVERGENCE)}

The decision of the Soviet elites and their course onto further integration of the USSR and the socialist camp into the world market (which in reality meant - into the world capitalist system) was determined by the fact that by mid-1960s the Soviet leadership actually refused to perform a stride from anticapitalism to postcapitalism, i.e., to what official party ideology termed as 'communism', and was looking for an alternative. It began to think about the convergence with capitalism hoping it would be admitted to the world economy on equal terms - it was precisely this choice which led the USSR to a catastrophe. 
There was a serious problem with the Soviet system. Being a negation of capitalism in the sphere of production relations, the Soviet system had as its material basis the same system of production (a Marxist would say 'productive forces') as capitalism did. To transform itself from anticapitalism to postcapitalism the USSR had to solve three problems:

1) to create a principally new system of economic management as a necessary condition for a new system of production (with a higher level of productivity);

2) to create a principally new system of energy - more powerful and less expensive than that based on oil;

3) to create a military-technological defence of the fulfillment of the first and second tasks (Fursov, 2017b, p. 633).

Did the USSR in the mid-1960s have a possibility and a potential to solve these problems and really outpass the stagnating capitalist West, the USA?

It definitely had.

In the first half of the 1960s, under the guidance of academician V.M. Glushkov, there was created the National Automatized System for Computation and Information Processing (OGAS). It made possible the scientific (cybernetic) governance of the Soviet society transforming it into an information one.

At the same time, a group of scientists under the guidance of I.S. Filimonenko finished the work of creating installations for cold thermonuclear synthesis. In fact, it was an invention of an extremely cheap source of energy that could close the oil industry forever as expensive and unnecessary ('Goodbye, the Rockefellers, the Rothschilds, etc.').

Finally, under the guidance of the Soviet genius in military air and space construction V.N. Chelomey, a serious breakthrough was achieved by means of which the USSR would outrun the USA in arms race by 30-40 years.

But none of these possibilities were realized. Glushkov's system frightened the US. According to American prognostications, if this system was installed by 1970, the USSR would outrun the US forever. It is no surprise that in 1964 under US President Lindon Johnson was organized the group 'To Stop Glushkov'. But even more frightened were Soviet upper groups - the nomenklatura, at least its leading part. If put into action, Glushkov's system could change the power balance in the USSR: it would led to the emergence of technocrats in power parallel to and independent from the so-called partocracy. That is why the nomenklatura did its best to 
block the introduction of Glushkov's system, and by 1970 it became evident that the OGAS would not be enacted.

As for cold thermonuclear synthesis, by the end of 1967, all works in this direction were also abandoned. By that time, at the upper layers of the Soviet state was formed a pyramid of a powerful group of those who had vested interest in oil trade and, consequently, in the integration into the world market and in the convergence with the West. This group did its best to bury Filimonenko's programme using an administrative resource.

Clan rivalries did not let Chelomey transform his inventions into innovations. Chelomey's counteragents used the détente as an argument against the development of the types of weapons elaborated in his construction office (Bodrikhin, 2014).

As a result, by the end of the 1960s, Soviet ruling groups, in fact, blocked transformation of anticapitalism into postcapitalism and chose integration into the capitalist system. No wonder that in the mid-70s, the West seized the historical initiative from the USSR and began a counteroffensive, which coincided with the neoliberal crack down of the middle and working classes in the West itself. At first, counteroffensive against the USSR aimed just to weaken it as much as possible. But in the early 1980s, the task was reformulated and came to mean destruction. The reason was very simple: grave perspectives for the capitalist system.

\section{THE TWILIGHT OF THE HISTORICAL 20th CENTURY (1981-1991)}

In late 1981, R. Reagan gave an order to organize three analytical groups. The task was to work out the scenarios of development perspectives of the capitalist system of the USA and the USSR. The groups were headed by prominent intellectuals - M. Gell-Mann (a Nobel Prize winner and the organizer of the Santa-Fe Institute), R. Collins (sociologist with close ties to the Bush family) and B. Bonner. The three groups were working separately from each other, but their prognostications coincided. All predicted a cyclical crisis of the world economy in 1987-88. The crisis was to cover both capitalist and socialist segments of the world economy. But, unfortunately for the USA, which would be busy with the confrontation with the USSR on the periphery of the world capitalist system, America would not be able to arrest or at least to weaken the crisis. As a result, in the early 1990s, the world economy would be hit by the depression, and its consequences would be much more serious and graver than that of the 1929-33 crisis. According to prognostications, the consequences for the West would be much harder than 
for the socialist camp (the decline of production by $15-20 \%$ in the West and just by $10-12 \%$ in the socialist segment of the world system). According to all three prognostications, the political results would be the following: the possibility of coming to power of communists in Italy, France and Spain; of left labour in Great Britain; mass racial and class riots in the largest US cities. After such prognostications, the destruction of the USSR became a question of life and death for the US, for the survival of the capitalist system.

What is interesting, a very pessimistic prognostication for the nearest future of the capitalist system was made in the early 1980s in the USSR by Pobisk Kuznetsov. According to his research, the functioning of the capitalist economic mechanism would lead in 1993-1995 to the situation in which the quantity of dollars in the world economy as compared to 1 kilowatt/hour of electric energy used in it would exceed the border magnitude. As a result, the hyperinflation of prices, commodities and assets would begin. This means, wrote Kuznetsov, that before the end of the $20^{\text {th }}$ century, the capitalist system would lie in ruins.

But in historical reality it was the USSR which was ruined while the West got almost 20 excessive 'fat years', thus cheating History. How could it have happened?

Despite all intentions of the West to destroy the USSR, the West could not do it alone - it was not strong enough for that. It had to find allies in the USSR. And it found them. In the USSR itself, at least since the mid-1970s, a group determined to change the social order in the country was formed. This group - 'a triple union' - was represented by some segments of the nomenklatura, some segments of the KGB, and shadow economy 'businessmen' largely of Georgian and Armenian origin, the latter having close ties with respective diasporas in France and the US. These close ties were exercised through the 'Spurk' - a semi-personal Armenian intelligence net organized by a Soviet leader Anastas Mikoyan. But without Western help, the triple union could not capitalize on the Soviet Union - it too had to find allies, and it found them. So there was formed an international double agent with two 'heads' - Soviet and Western.

The larger part of the Soviet 'brigade' did not want to destroy the USSR altogether; perhaps it was ready just to let go some of the republics - and that was all. They wanted to change the social order. But in the course of actions by the end of 1988, they lost control of the process. The West (the USA of G. Bush Senior) got the upper hand, ceased the initiative. Combined with the Yeltsin factor in 1991, it led to the destruction of the USSR, both as the anticapitalist order and the state. In 1991 began the Age of Turbulence. 
It began with the plunder of the ex-socialist zone of the world economy, first of all of the former USSR and GDR.

While in 1989 in Eastern Europe, including the European part of the USSR, lived $14 \mathrm{mln}$ below the poverty line, in 1996 their number soared to $168 \mathrm{mln}$. It is no surprise that in the last three years of Clinton's second term, the US had a budget surplus for the first time in 30 years. Due to this plunder, the capitalist system got almost 20 'fat years'. This was provided by three factors.

1) With the end of the Cold War, the world market was flooded by cheap natural resources - fuel-energetic (oil, gas), chemical, metallic. It was the result of the privatization of Russian industry.

2) Simultaneously, there was an unprecedented (since the times of Soviet industrialization) rise of foreign investment in China. Cheap Chinese products immensely favoured a consumption boom all over the world.

3) The NATO countries lowered their military expenses for a while, and a part of the funds was transferred to the sphere of social programmes. By 2007-2008, the 'basket luncheon' of the 'fat years' was over - nihil dat fortuna mancipio, and there came a crisis. It was neither solved nor overcome. It was just inundated, flooded with money. It did not go away, just slowed down, and is very likely to resurrect in 2020-2021. Since this crisis is not just purely structural as that of 1929-1933, it is systemic - part and parcel of a general (I stress: systemic and not structural), i.e., the terminal crisis of capitalism.

The absence of the USSR changed the world situation at least in three directions:

1) With the USSR, the only force which contained the West in its imperialist inspirations faded away, be it in Cuba, Vietnam, or Angola. World politics without the Soviet Union became the world of imperialist, mainly Anglo-American gangsterism: Yugoslavia, Afghanistan, Iraq, and Libya, fell victim to it. At the beginning of the $21^{\text {st }}$ century, the US, Great Britain, and their allies settled down to the realization of their geopolitical programme in the Middle East and Africa: splitting up states into ministates convenient for exploitation by transnational corporations.

2) Without the USSR with its social achievements, the dominant groups in the West actively began to dismantle the social achievements of the welfare state. The offensive actions against the middle and working classes began 10 years before the destruction of the USSR (Thatcherism in Great Britain, Reaganomics in the USA), but only after the said destruction, these actions could acquire full swing. It is no surprise that by 2010 social and 
economic inequalities in the core capitalist countries returned to the level of 1910 - to the norm of capitalist society, as was shown by T. Piketty in his seminal work 'Capital in the $21^{\text {st }}$ Century'. Since 1945 capitalists were forced to violate this norm and make capitalism look social against its nature largely because of the existence of the Soviet Union. The return to the norm was the direct result of the destruction of the USSR.

3) The Cold War demanded a high measure of the unity of the Western elites (Fursov, 2017a). Of course, there were different contradictions between different groups of North Atlantic elites as well as inside them, and the USSR tried to use and exploit these contradictions. Yet in the Soviet epoch of world history, the North Atlantic elites did their best to consolidate their efforts, especially in the late 1980s, when even West German elites (after 1988) decided to join the process of the destruction of the Soviet Union. Now, at the beginning of the $21^{\text {st }}$ century, the Western elites having no common enemy and facing the terminal crisis of capitalism found themselves in the situation approaching civil war - at least Brexit and the whole Trump affair testify about it. It is clear that all these trumps-macrons-obamas-blairs-etc. are the puppets of the real Masters of the game. Of course, I am not going to put anybody of this bunch of high-ranking clerks with the Dutch royal family, the dukes of Lorrain and Lichtenstein, or the dukes of Furstenberg and some other families of the Western European grid which formed by the mid- $17^{\text {th }}$ century and later organized its semiclosed service structures. When I recite the names of presidents, etc., I just define the superficial, surface dimension of the real struggle. Inter-elite war for the future - between different clans, globalists and the so-called 'patriots', between radical globalists and moderate globalists - is a feature of the Age of Turbulence. The principle is: who will cut off whom from the future. The whole situation is aggravated by a catastrophic climatic change.

I believe we are witnessing the last multidimensional hunt of the Capitalist Age. And our task is to change places with the hunter and transform him into a game. Is it cruel? Undoubtedly. But is not the hunter himself merciless and cruel? Yes, he is. So for our part nothing personal, just business - the business of making History.

\section{CONCLUSION}

The Age of Turbulence (1991-2021), which is coming to an end opening the gates to the Terminal Age (of capitalism), was the result of the realization of interests of parts of Western dominant groups and parts of the Soviet 
nomenklatura. Both groups wanted to keep their power, property and privileges by slowing down scientific-technological progress, by the financialisation of the economy, and - in fact - dismantling of capitalism. However, the dismantling of capitalism presupposed the dismantling of systemic anticapitalism and the destruction of the USSR. These events postponed the systemic crisis of capitalism for 20 years, but the dark side of the postponing was the chaotizaton of the world economy and world political turbulence, and - in the long run - the speeding up of the terminal phase of the crisis: one can cheat History, but only for a very short time, and after that, the cheater has to pay dearly (Fursov, 2017c).

\section{REFERENCES}

Bodrikhin, N. (2014). Chelomey. Moscow, Molodaya gvardiya.

Fursov, A.I. (2017a). Kholodnaya voina, sistemnyi antikapitalizm i Peresdacha Kart Istorii [Cold War, Systemic Anticapitalism and the Redeal of the Cards of History] in: Fursov, A.I. Mirovaya bor'ba: anglosaksy protiv planety [World Struggle: The Anglosaxons against the Planet]. Moscow, Knizhny mir, 2017. pp. 311-390.

Fursov, A. I. (1996). Kolokola Istorii [The Bells of History]. Moscow, INION RAN.

Fursov, A.I. (2017b). Tsepi nastoyashchego, sily proshlogo i bitvy budushchego [The Chains of the Present, the Forces of the Past and the Battles of the Future] in: Fursov A.I. Bor'ba voprosov. Ideologiya $i$ psikhoistoriya [The Struggle of Questions. Ideology and Psychohistory]. Moscow: Knizhny mir, 2017. pp. 578-762.

Fursov, A.I. (2017c). XXI vek - mir bor'by i bor'ba mirov [Twenty-first Century - the World of Struggle and the Struggle of Worlds] in: Fursov A.I. Mirovaya bor'ba: anglosaksy protiv planety [World Struggle: The AngloSaxons against the Planet]. Moscow: Knizhny mir, 2017. pp. 482-510. 